Lidia D. CZARKOWSKA ${ }^{1}$

\title{
FOUR PILLARS OF PERSONAL AGENCY OF AN ENTREPRENEUR: HARMONY IN EMOTIONS, CAUTIOUSNESS IN THINKING, RESPECT IN RELATIONS AND COURAGE IN ACTION
}

\begin{abstract}
The article presents the context and individual determinants of entrepreneurial success, including both structural (socio-political, economic, technological, legal) and individual factors. The author presents a review of models outlined in literature and defines entrepreneurship in the following categories: sets of personality traits, a description of attitudes, specific skills, actions and processes. Results of research on entrepreneurial characteristics, attitudes, motivations and actions are also outlined. The model of Homo Hubris - an ideal entrepreneur, capable of transgressive behaviour - is referred to in the context of personality concepts. The author also outlines a list of features and characteristics that hinder and those that, conversely, facilitate entrepreneurial actions, with a special emphasis on the role of a generalized sense of self-efficacy. Furthermore, a range of business coaching applications is discussed, as well as the objectives and benefits stemming from this type of specialized service aimed at business owners. In the application section of the article, the author's model of "four pillars of personal agency of entrepreneurs: harmony in emotions, cautiousness in thinking, respect in relationships and courage in action" is discussed. The author also discusses an example of the application of this model during a group coaching session for 41 entrepreneurs participating in the project "Entrepreneurship in the creative sector". Among the main benefits of participation in the business coaching process, participants referred to the identification of their own personal resources, strengths and talents, as well as areas for further development; greater clarity in planning activities and setting priorities; improved ability to manage their emotional state; strengthening internal motivation, commitment and consistency; greater sense of agency, proactive approach and the development of social skills to be used for establishing and deepening relationships with clients, colleagues and clients.
\end{abstract}

Keywords: coaching, entrepreneurship, emotional intelligence, intrinsic motivation, creative sector.

\section{INTRODUCTION}

What sets the limits of action for entrepreneurs and determines their chances to succeed? In order to answer this question, we must consider both external, systemic factors affecting business activities, and internal, personal factors, pertaining to the motivation and competences of entrepreneurs.

\footnotetext{
${ }^{1}$ Lidia D. Czarkowska PhD, Coaching and Mentoring Centre and the Department of Social Sciences; Kozminski University, 03-301 Warszawa, ul. Jagiellońska 57/59, lidia@kozminski. edu.pl (+48) 225192244
} 
Political and economic freedom that had been fought for and later built following the advent of democracy and the development of free market economy has both provided Poles with access to a wide range of possibilities and generated an acute sense of uncertainty $^{2}$. From the 1950 s to the 1980 s, Poles struggled on a daily basis in the "reality of endless shortage" of goods, services and - perhaps most importantly - possibilities. Back in the day, in most unfavourable conditions, only exceptionally enterprising individuals would seek opportunities and legal gaps allowing them to run private firms regardless despite the crippling restrictions imposed by the system of centrally planned economy.

In today's Poland, life and professional challenges have shifted towards Western European standards and they now emanate from the opposite situation, namely the omnipresent excess of everything. Along with political and economic changes that have taken place in Poland over the last thirty years, as well as the process of globalization and rapid technological progress, a wide range of possibilities has, at least potentially, opened up in almost every domain of life. This results in a certain decision paralysis, paradoxically due not to the shortage, but the excess of available information, to the multiplicity of options and choices.

In order to ensure the picture is complete, we should also take into account the sociocultural changes, as a result of which generations of people born in the 1980s and 1990s, called "Generation $Y$ " and those born in the $21^{\text {st }}$ century, referred to as "Generation C", have grown up under completely different social, cultural, economic and technological circumstances and they have been raised with different sets of common beliefs. When together with the introduction of democracy and free market economy, systemic barriers to individual business initiatives were lifted, a sudden wave of optimism brought along with it slogans prompting proactive attitudes: "to want is to be able to", "you can do anything - the choice is yours" and "developing you potential is a guarantee of success". The widely proclaimed freedom of choice and success stories about spectacular careers and business ventures, quickly acquired wealth and luxurious lifestyles still incite many to set themselves ambitious goals and magnify, sometimes excessively, their thirst for success.

Still, when choosing one's path in life, one has to take into account certain "hard" constraints, namely the available financial resources, time and legal regulations; the latter, on the other hand, are a guarantee of personal freedom, civil liberties, social and economic rights, as well as tolerance for individual lifestyle choices. Global economic changes, which have a significant impact on local supply and demand, the incessant technological development, innovations in the manufacturing of goods and the provision of services also inevitably deepen the feeling of uncertainty.

It is therefore all the more important now to understand how an individual can - using internal resources - enhance his/her personal agency in order to maintain control within this constantly changing environment and influence his/her own situation. In this environment, characterized by a multiplicity of options, growing complexity and diversity of contexts, substantial demand for business coaching is observed, as it can offer a number

\footnotetext{
${ }^{2}$ Koźmiński A.K., Zarządzanie $w$ warunkach niepewności. Wydawnictwo Naukowe PWN, Warszawa 2004.
} 
of useful methods to help us make the right choices, consistent with our value system and, in the case of entrepreneurs, facilitating strategic and tactical decisions ${ }^{3}$.

\section{CONTEXTUAL AND PERSONAL FACTORS OF ENTREPRENEURIAL SUCCESS}

When we examine the economic and legal background of entrepreneurship development in Poland, we come across ample information on objective indicators that can be used for the purposes of comparative assessment of business conditions. In order to learn more about the so-called general environment - i.e. common to all firms operating in Poland - it seems advisable to conduct the PEST ${ }^{4}$ analysis, taking into account the following dimensions: 1) political and legal, 2) economic and financial, 3) socio-cultural, and 4) technological.

The organizational environment is assessed, inter alia, through international rankings based on global research; in recent years, their results have indicated a gradual (though not in every aspect) improvement of the situation in Poland (Table 1).

Table 1. Poland in international competitiveness rankings in 2010-2014

\begin{tabular}{|c|c|c|c|c|c|}
\hline Competitiveness rankings & $10^{20}$ & $11^{20}$ & $12^{20}$ & $13^{20}$ & $14^{20}$ \\
\hline Doing Business & 73 & 70 & 62 & 55 & 45 \\
\hline Global Competitiveness Index & 46 & 39 & 41 & 42 & 44 \\
\hline The Heritage Foundation & 68 & 87 & 64 & 57 & 50 \\
\hline
\end{tabular}

Source: own study based on Krajewski 2014

In the Doing Business $2014^{5}$ report published by the World Bank, Poland ranked $45^{\text {th }}$ among 189 countries. The study takes into account the impact of the legal environment on ten key business areas, namely: 1) starting a business, 2) dealing with construction permits, 3) hiring employees, 4) registering property, 5) getting credit, 6) protecting minority investors, 7) paying taxes, 8) trading across borders, 9) enforcing contracts, 10) resolving insolvency (http://www.doingbusiness.org). In the Global Competitiveness Index of the World Economic Forum (GCI), which takes into account the wider context and includes 12 areas affecting the development of entrepreneurship, namely: 1) institutions, 2) infrastructure, 3) macroeconomic environment, 4) health, 5) primary and higher education, 6) goods market efficiency, 7) labour market efficiency, 8) financial market development, 9) technological readiness, 10) market size, 11) business sophistication and 12) innovation ${ }^{6}$, Poland ranked $44^{\text {th }}$ among 148 countries (2014). The Index of Economic Freedom is a report prepared by "The Wall Street Journal" and Heritage Foundation and it includes a description and assessment of economic freedom,

${ }^{3}$ Czarkowska L.D., Business-Coaching a cechy, motywy $i$ działania przedsiębiorcze. Sztuka dokonywania wyborów i podejmowania decyzji w coachingu dla przedsiębiorców, [in:] BusinessCoaching jako dźwignia rozwoju przedsiębiorczości, Poltext, Warszawa 2015a, s. 35-55.

${ }^{4}$ Obłój K., Strategia organizacji. W poszukiwaniu trwatej przewagi konkurencyjnej, Polskie Wydawnictwo Ekonomiczne, Warszawa 2007, p. 211.

${ }^{5}$ Krajewski K., 2014 http://bizneslokalny.pl/2014/05/przedsiebiorczosc-w-polsce-w-raportachmiedzynarodowych/ access: June 2016.

${ }^{6} \mathrm{http}: / /$ www.weforum.org/. 
i.e. limitations and restrictions imposed on entrepreneurs and businesses by state authorities; in 2014, Poland ranked $50^{\text {th }}$ among 178 countries $^{7}$.

When examining personal factors that determine the success of an entrepreneur, it seems advisable to resort to the results of quantitative and qualitative research, taking into account characteristic features, as well as competences, attitudes and motivations ${ }^{89}$.

In everyday context, the adjective "entrepreneurial" is most often used to describe a person characterized by agility, acumen, resourcefulness and the spirit of initiative. An enterprising person is inventive, energetic and courageous, effectively responds to various situations, is capable of making decisions, taking appropriate actions and risks, and easily adapts to the changing environment ${ }^{10}$. Many definitions of this concept can be found in literature. Entrepreneurship is defined as 1) a set of personality traits, 2) a particular attitude, 3) a specific type of behaviour (actions), 4) a process (undertaking) ${ }^{11}$, as well as 5) specific economic functions performed, and even 6) a management style ${ }^{12}$.

In the on-going debate whether entrepreneurship is an innate and permanent personality trait, or whether it can be learnt, no universal agreement has yet been reached, even in terms of a universal set of traits typical of an entrepreneurial personality ${ }^{13}$. Nevertheless, the results of empirical research induce authors to create lists of characteristic features that distinguish entrepreneurs. It typically includes creativity (ingenuity), consistency, responsibility, expertise (competencies), decisiveness, courage, assertiveness, appropriate appearance, strong character, self-control, communicativeness, resourcefulness, efficiency, readiness to take risks, work discipline, self-confidence and a proactive approach ${ }^{14}$. Among the characteristics of entrepreneurs, Karlöf emphasizes the importance of the following six traits: a) ability to make independent decisions, b) desire to dominate, c) desire to generate profit, d) strong need for achievement, e) spirit of initiative and f) putting high demands on oneself and others ${ }^{15}$.

Personality traits of entrepreneurs have been examined and discussed at length ${ }^{16}$. Lesław Haber ${ }^{17}$ claims that the ideal personality model for an entrepreneur is Homo

\footnotetext{
${ }^{7}$ http://www.heritage.org/index/ranking.

${ }^{8}$ Piecuch T., Przedsiębiorczość. Podstawy teoretyczne. Wydawnictwo C.H. Beck, Warszawa 2010, p. 37.

9 Piasecki B. (red.), 2001. Ekonomika i zarzadzanie mała firma. Wydawnictwo Naukowe PWN, Warszawa-Łódź 2001, p. 23.

${ }^{10}$ Sudoł S., Przedsiębiorczość - jej pojmowanie, typy $i$ czynniki ja ksztaltujące. Problemy Zarządzania, 2008, 2/2008(20), s. 9-26.

${ }^{11}$ Piecuch T., Przedsiębiorczość..., op. cit.

${ }^{12}$ Piasecki B., Ekonomika..., op. cit.

${ }^{13}$ Szewczuk W. (ed.), Encyklopedia psychologii. Fundacja Innowacja, Warszawa 1998, s. 468.

${ }^{14}$ Piecuch T., Cechy przedsiębiorcy. Ekonomika i Organizacja Przedsiębiorstwa, 2009, vol. 2, no. 708 , s. 23.

${ }^{15}$ Karlöf B., Business Strategy. A Guide to Concepts and Models. The Macmillan Press Ltd., London 1989.

${ }^{16}$ Strzałecki A., Czołak D., Osobowościowe i temperamentalne czynniki warunkujące osiaganie sukcesu w przedsiębiorczości. Przegląd Psychologiczny, 2005, vol. 48, no. 2, s. 133-151.

${ }^{17}$ Haber L.H., Przedsiębiorczość rynkowa parametrem produktywności człowieka $w$ procesach pracy. Humanizacja Pracy, 1997, 4(178), s. 14-23.
} 
hubris, i.e. an individual driven by hubristic motivation ${ }^{18}$. According to this model, the perfect entrepreneur - Homo hubris - is characterized by 1) a strong need for achievement, 2) high levels of risk tolerance, 3) non-conformism with respect to rules, 5) high selfesteem, and 6) readiness to take transgressive action.

Entrepreneurial transgression in his approach means "continuous expansion of one's area of physical, intellectual, manual or mental possibilities, extending the limits of cognition, tearing down barriers and stereotypes, establishing new firms and undertaking entrepreneurial activities"19.

The analysis of empirical data collected in the 1980s and 1990s shows that the links between personality traits defined by subsequent theorists and entrepreneurship itself are rather weak and unsystematic ${ }^{20}$. Furthermore, given the absence of a general agreement on a universal set of traits typical of the entrepreneurial personality ${ }^{21}$ and the fact that those who achieve business success may represent very different personality types, we should refrain from further exploring this path ${ }^{22}$.

Most convincing data has been collected in relation to the positive correlation between entrepreneurship and the need for achievement ${ }^{23}$, first described by Henry Murray, and later popularized by David McClelland ${ }^{24}$.

It was not until the beginning of the $21^{\text {st }}$ century that, following the popularization of the five factor model of personality traits - neuroticism (vs. emotional stability), extroversion, openness to experience, agreeableness and conscientiousness - called the Big Five, several meta-analyse ${ }^{2526}$ of research results were conducted in order to enhance the control of research methodology and statistical evaluation of the strength of identified regularities ${ }^{27}$. As the model assumes that the basic structure of personality traits of an adult is determined biologically, stable and universal, that is, virtually independent of culture $^{28}$, it can be concluded that the results of any research carried out in this area can be also applied to Poland. Meta-analyses have confirmed that the three features of the Big

${ }^{18}$ Kozielecki J., O czlowieku wielowymiarowym. Eseje psychologiczne. Wydawnictwo Naukowe PWN, Warszawa 1988.

${ }^{19}$ Haber L.H., Przedsiębiorczość rynkowa..., op. cit. s. 16.

${ }^{20}$ Kaczmarek M., Kaczmarek-Kurczak P., Przeglad metaanaliz dotyczacych zwiazku cech osobowości i przedsiębiorczości. W stronę modelu badań. Management and Business Administration. Central Europe, 2012, no. 108, p. 49-63.

${ }^{21}$ Szewczuk W. (ed.), Encyklopedia..., op. cit.

22 Gartner W.B., Who is an entrepreneur? Is the wrong question. Entrepreneurship Theory and Practice, 1988, vol. 13, p. 47-68.

${ }^{23}$ Collins Ch.J., Hanges P.J., Locke E.A., The relationship of achievement motivation to entrepreneurial behavior: A metaanalysis. Human Performance, 2004, vol. 17, p. 95-117.

${ }^{24}$ McClelland D.C., Need achievement and entrepreneurship: A longitudinal study. Journal of Personality and Social Psychology. 1965, vol. 1, p. 389-392.

25 Rauch A., Frese M., Let's put the person back into entrepreneurship research: A meta-analysis on the relationship between business owners' personality traits, business creation, and success. European Journal of Work and Organizational Psychology", 2007, vol. 16, p. 353-385.

${ }^{26}$ Zhao H., Seibert S.E., The Big Five personality dimensions and entrepreneurial status: A metaanalytic review. Journal of Applied Psychology. 2006, vol. 91, p. 259-271.

${ }^{27}$ Zhao H., Seibert S.E., Lumpkin G.Th., The relationship of personality to entrepreneurial intentions and performance: A metaanalytic review. Journal of Management. 2010, vol. 36, p. 381-404.

${ }^{28}$ Kaczmarek M., Kaczmarek-Kurczak P., Przegląd metaanaliz..., op. cit. p. 53. 
Five model are significant predictors of both one's intention to set up a business and one's success as an entrepreneur. Conscientiousness and openness to experience seem most closely linked to entrepreneurship, while neuroticism, which is the opposite of emotional stability, has turned out to be relatively the weakest predictor (although not negligible).

Another "Big Five" trait that deserves particular attention is self-efficacy. In their meta-analysis, Rauch and Frese prove this trait to be particularly important ${ }^{29}$, and $r$ values calculated for it are highest among all analysed personality variables; they amount to $r=0.38$ for business creation and $r=0.25$ for the company's success ${ }^{30}$. For this reason, in the proposed model of the four pillars of personal agency entrepreneurs benefit most from enhanced self-efficacy.

Individuals with a strong sense of self-efficacy are also proactive, have and internal locus of control, believe to be actively creating their reality. They regard problems and difficulties as challenges, have a high level of confidence, the ability to cope and strive assiduously to achieve their objectives despite obstacles they may encounter. In crisis situations, they rely on more constructive methods of dealing with problems: they develop long-term plans and are actively looking for information ${ }^{31}$.

In addition to the strand of research aimed at defining the set of personality traits that characterize entrepreneurs, there is a wide range of studies examining entrepreneurship in terms of actions. On the one hand, entrepreneurial attitudes ${ }^{32}$ and motivations ${ }^{3334}$ are revealed in actions; on the other hand, taking action is an opportunity to develop entrepreneurial competencies ${ }^{35}$.

\section{BUSINESS COACHING: TRAITS, MOTIVATIONS AND ACTIONS OF ENTREPRENEURS}

The vast majority of researchers are of the opinion that entrepreneurship is not conditioned by immutable personality traits, but can be learnt. In their view, entrepreneurship is a special attitude, or a specific type of action that can be trained and shaped in the process of socialization ${ }^{36}$. Entrepreneurship understood as the attitude of an individual towards the environment is expressed in the creative and active effort to

${ }^{29}$ Rauch A., Frese M., Let's put..., op. cit.

${ }^{30}$ Kaczmarek M., Kaczmarek-Kurczak P., Przegląd metaanaliz..., op. cit.

${ }^{31}$ Benight Ch.C., Cieslak R., Cognitive factors and resilience: how self-efficacy contributes to coping with adversities, [w:] Resilience and mental health: Challenges across the lifespan. (eds.) S.M. Southwick, B.T. Litz, D. Charney, M.J. Friedman, Cambridge University Press 2011.

${ }^{32}$ Strojny J., Kształtowanie postawy przedsiębiorczej - procesy socjalizacji i autokreacji, [in:] Ksztaltowanie postaw przedsiębiorczych a edukacja ekonomiczna, Fundacja Promocji i Akredytacji Kierunków Ekonomicznych, Warszawa 2007.

${ }^{33}$ Praszkier R., Zwykli ludzie czy herosi? Motywacje przedsiębiorców społecznych. Trzeci Sektor, 2006, nr 4, s. 35-42.

${ }^{34}$ Dylkiewicz R.B., Zarzadzanie przez motywacje $w$ procesach podejmowanych decyzji gospodarczych. Przedsiębiorczość i zarządzanie, 2013, vol. XIV, no. 3, s. 87-98.

${ }^{35}$ Kalita B., Przedsiębiorczość jako kompetencja kluczowa w procesie uczenia się przez całe życie. Zeszyty Naukowe Politechniki Śląskiej. Seria Organizacja i Zarządzanie, 2014, z. 72, s. 51-64.

${ }^{36}$ Kraśnicka T., Koncepcja rozwoju przedsiębiorczości ekonomicznej $i$ pozaekonomicznej. Wydawnictwo AE, Katowice 2002, p. 592. 
improve one's situation, in willingness to take action and adapt the existing strategies, as well as the desire to achieve material gains ${ }^{37}$.

Peter Drucker also clearly states that entrepreneurship is not a personality trait, as successful entrepreneurs form a heterogeneous group that includes individuals with opposing types of temperaments. The art of dealing with uncertainty, exploration and implementation of innovation, maximizing opportunities and applying strategies and practices that are congruent with the intended purposes can be learnt ${ }^{38}$.

A generative approach to the individual, which assumes sine qua non each person's growth potential and the ability to change his/her behaviour and actions, is fundamental for coaching. For this reason, entrepreneurship in business coaching is not treated as a fixed set of personality traits, but as a set of skills and strategies that facilitate transgressive action, which can be acquired, learnt and trained through conscious, targeted and systematic work on oneself ${ }^{39}$.

As part of the business coaching process, emphasis can be placed on individual goals: thus, it will become a specialized service targeted at a specific group, i.e. entrepreneurs who wish to set up or are already running a business and intend to expand it, aiming to build a successful firm mainly through the development of self. This form of coaching will benefit in particular the owners of small or medium-size enterprises and professionals running their own business. If the coach works directly with the entrepreneur, the coaching process may address to a greater extent the personal assets of the firm owner, his/her behaviour and competences, beliefs and values, as well as the vision of life and mission, which also encompasses his/her actions taken as an entrepreneur.

In terms of objective goals, business coaching can be applied to any firm, regardless of its size: from one-person businesses to international corporations. It is understood as a process focused on the firm's interests, on streamlining its operations, facilitating its development, on expansion and profit generation. This effect can be achieved through systemic work with the organisation's key decision-makers, with coaching conducted at the board level ${ }^{40}$ and through working with leaders, those having a particular impact on processes taking place within the organization, innovators and high potential individuals. The essence of this process is to translate the corporate vision into a strategy, ideas into actions, and to provide support to individuals and teams in the on-going process of goal achievement.

In practice, the two approaches to the process of business coaching - subjective and objective - are often intertwined. External results (measurable outcomes) are considered to be the effect of competence development and the selection of appropriate measures by those who are jointly involved in the functioning of the company.

In conclusion, we can say that it facilitates the process of making strategic decisions and key choices by clients through three basic functions: 1) expanding their self-

${ }^{37}$ Wiatrak A.P., Pojęcie przedsiębiorczości, jej cele i rodzaje, [in:] K. Jaremczuk (red.) Uwarunkowania rozwoju przedsiębiorczości - szanse i zagrożenia. Wydawnictwo Państwowej Wyższej Szkoły Zawodowej, Tarnobrzeg 2003.

${ }^{38}$ Drucker P.F., Innovation and Entrepreneurship, Heinemann, London 1985.

${ }^{39}$ Czarkowska L.D., Business-Coaching..., op. cit.

${ }^{40}$ Czarkowska L.D., Zarządzanie zintegrowane $i$ coachingowy pierścień transformacji jako narzędzie rozwoju świadomości, [in:] Coaching jako wskaźnik zmian paradygmatu $w$ zarzqdzaniu. Poltext, Warszawa 2012. 
awareness, 2) strengthening their capacity for self-regulation and 3) supporting the process of planning, implementation and verification of actions taken by entrepreneurs (see Fig. 1).

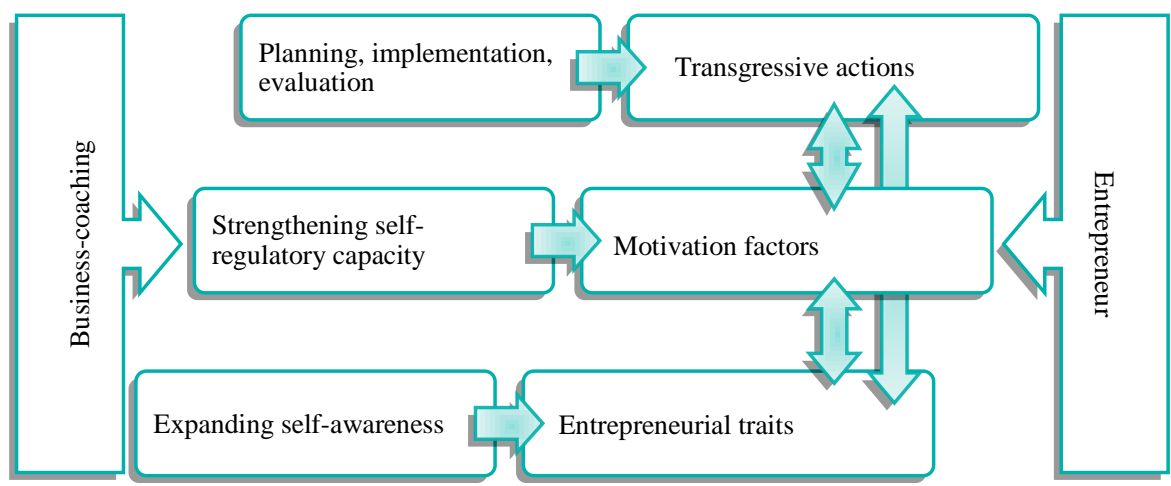

Fig. 1. Functions of business coaching

Source: own study based on Czarkowska L.D. 2015a.

Systematic expansion of the client's self-awareness is of utmost importance for business coaching. It can be achieved through targeted observation of habitual patterns of behaviour, analysis of actions taken and results achieved, as well as openness to feedback. For this reason, it may be useful to refer to the list of traits (permanent or variable) that can facilitate or hinder taking entrepreneurial actions (Table 2).

The list presented in Table 2 - just as any attempt to synthesise the results of several studies undertaken on the basis of different theoretical assumptions and carried out on non-comparable empirical samples - can naturally be considered arbitrary and simplified. Therefore, it should not be used outside of the situational context in which the entity operates, and it certainly should not be regarded as a tool for assessing the potential of individual entrepreneurs. It can be resorted to for coaching purposes, as a list of characteristics representing a point of reference for independent, in-depth reflection on behavioural strategies and their relevance for the goals set.

In business coaching, in addition to the entrepreneur's self-reflection on a set of personality traits, it is of utmost importance to identify personal motivation factors determining the person's ability to create and develop business activities. The motivation of entrepreneurs has been subject to a great number of studies and a wide spectrum of factors that motivate people to take up the role of an entrepreneur has been outlined. According to Maslow's classic model, motivation sources must be sought among the individual's unfulfilled needs ${ }^{41}$.

Importantly, the pursuit of profit maximization is not the main material factor that triggers the individual's readiness to start a business. Naturally, profit as the primary indicator of any business's effectiveness is important, but, as Peter Drucker notes, "the primary test of any business is not the maximization of profit, but the achievement of

\footnotetext{
${ }^{41}$ Maslow A.H., Towards a Psychology of Being, Princeton 1962, N.J.: D. Van Nostrand Co.
} 
sufficient profit to allow for the risks of the financial activity of the business" ${ }^{42}$. Regarding profit maximization as the firm's primary goal can be downright dangerous, as it may hinder investment in its development and adaptation to rapidly changing market conditions.

Table 2. Traits that hinder and facilitate entrepreneurial activities

\begin{tabular}{|c|c|c|}
\hline Hindering traits & Categories & Facilitating traits \\
\hline $\begin{array}{l}\text { External locus of control } \\
\text { Submission } \\
\text { Reliance on care and support }\end{array}$ & $\begin{array}{l}\text { Psychological } \\
\text { needs }\end{array}$ & $\begin{array}{l}\text { Internal locus of control containment } \\
\text { Domination } \\
\text { Pursuit of autonomy }\end{array}$ \\
\hline $\begin{array}{l}\text { "From" motivation - avoidance } \\
\text { Fears and concerns } \\
\text { Desire to maintain one's holdings } \\
\text { Weak need for achievement }\end{array}$ & Motivation & $\begin{array}{l}\text { "Towards" motivation - pursuit } \\
\text { Pursuit of achievement and success } \\
\text { Desire to multiply one's holdings } \\
\text { Strong need for achievement }\end{array}$ \\
\hline $\begin{array}{l}\text { Indecisiveness } \\
\text { Instability } \\
\text { Reactivity } \\
\text { "Learned helplessness" }\end{array}$ & Decisions & $\begin{array}{l}\text { Decisiveness } \\
\text { Consistency } \\
\text { Proactivity } \\
\text { Resourcefulness } \\
\end{array}$ \\
\hline $\begin{array}{l}\text { Treating risky situations as a threat } \\
\text { Avoiding risky situations and } \\
\text { decisions }\end{array}$ & Risk & $\begin{array}{l}\text { Treating risky situations as a challenge } \\
\text { or opportunity } \\
\text { Willingness to take risky decisions and } \\
\text { actions }\end{array}$ \\
\hline $\begin{array}{l}\text { Lack of mental toughness } \\
\text { Low stress and frustration threshold } \\
\text { Withdrawal and denial in difficult } \\
\text { situations }\end{array}$ & $\begin{array}{l}\text { Success and } \\
\text { failure }\end{array}$ & $\begin{array}{l}\text { Mental toughness } \\
\text { High stress and frustration threshold } \\
\text { Active approach to difficult situations } \\
\text { and taking action }\end{array}$ \\
\hline $\begin{array}{l}\text { Traditionalist attitude } \\
\text { Conservatism } \\
\text { Conformity } \\
\text { Lack of creative abilities }\end{array}$ & $\begin{array}{l}\text { Innovativeness } \\
\text { and creativity }\end{array}$ & $\begin{array}{l}\text { Pioneering attitude } \\
\text { Openness to innovation } \\
\text { Nonconformity } \\
\text { Creativity }\end{array}$ \\
\hline $\begin{array}{l}\text { Isolation } \\
\text { Lack of trust in people } \\
\text { Lack of leadership skills } \\
\text { Lack of negotiation and } \\
\text { mobilization competences }\end{array}$ & Cooperation & $\begin{array}{l}\text { Cooperation and competition } \\
\text { Trust in people } \\
\text { Leadership abilities } \\
\text { Ability to negotiate and mobilize } \\
\text { others }\end{array}$ \\
\hline $\begin{array}{l}\text { Pessimism } \\
\text { Cognitive inflexibility } \\
\text { Passivity, laziness } \\
\text { Anxiety, fear, withdrawal }\end{array}$ & $\begin{array}{c}\text { Reaction to } \\
\text { barriers }\end{array}$ & $\begin{array}{l}\text { Optimism } \\
\text { Cognitive flexibility } \\
\text { Activity, diligence } \\
\text { Hope and perseverance }\end{array}$ \\
\hline $\begin{array}{l}\text { Melancholic/Phlegmatic } \\
\text { Introversion } \\
\text { Low energy levels } \\
\text { Frail nervous system }\end{array}$ & Temperament & $\begin{array}{l}\text { Sanguine/Choleric } \\
\text { Extraversion } \\
\text { High energy levels } \\
\text { Resistant nervous system }\end{array}$ \\
\hline
\end{tabular}

Source: own study based on Wiatrak 2003., p. 31; Piecuch 2010, p. 62 and Sudoł 2008, p. 18 - cf. Czarkowska L.D. 2015a.

\footnotetext{
${ }^{42}$ Drucker P.F., Peter Drucker on the Profession of Management, Harvard Business School Publishing, Boston 1998, s. 51.
} 
Among material factors that have triggered their decision to set up a business, Polish respondents quite often refer to necessity, i.e. unemployment or the desire to generate extra income to supplement insufficient salaries or pensions ${ }^{43}$. Such entrepreneurs are dubbed "coerced entrepreneurs", as opposed to "opportunity entrepreneurs", who have been identified as those who set up their business as a response to an opportunity they have perceived, e.g. a particular idea, access to a suitable space, lack of competition in a particular sector of products or services, or access to co-financing from EU funds ${ }^{44}$.

Naturally, a number of important non-material factors that may encourage one to become an entrepreneur should also be taken into account. These include: 1) the desire to achieve independence, self-reliance and autonomy in decision-making, 2) the need to dominate, to gain competitive advantage, to become a leader in a particular field, to influence, 3) the need for acknowledgement, respect, social stature within a community, 4) the need for achievement, 5) the need for self-realization, and even 6) transpersonal needs: to serve the community and to pursue one's ideals. In the process of business coaching, the coach should ask the entrepreneur about his/her definition of success in terms of both material and non-material aspects; subjective (self-fulfilment and satisfaction) and objective (measurable indicators); internal (reference to each other) and external (as compared to others) ${ }^{45}$.

\section{FOUR PILLARS OF PERSONAL AGENCY OF AN ENTREPRENEUR - MODEL}

The author's model of "four pillars of personal agency" has been created together with Artur Rzepecki, initially for the purposes of coaching leaders; however, given the nature of activities in the area requiring independence in decision-making, it proved extremely useful for business coaching.

For the purposes of developing the model, four areas were first determined: two internal (the intrapersonal dimension): thinking/reflection and emotions, as well as two external (the interpersonal dimension) - actions and relationships. It should be noted that each of these areas relates to a different set of aptitudes and competencies, hence the resulting ease or difficulty in moving freely and in effectively managing one's actions within them depends on each person's talents and skills. Some entrepreneurs are extremely agile in thinking, yet not as effective in understanding and managing their own emotions, or vice versa. Certain leaders are determined in action, but incapable of skilfully building relationships conducive to the achievement of team goals or, conversely, they excel in creating a good atmosphere, but prove ineffective in enforcing satisfactory results. Rare are leaders who are proficient in all of these aspects; they can be extremely effective and, at the same time, create profound relationships, establish long-term cooperation and encourage the involvement of others.

\footnotetext{
${ }^{43}$ Kulawiak A., Spoteczne uwarunkowania rozwoju sektora ustug w matych miastach. Przyktad Uniejowa. Acta Universitatis Lodziensis, Folia Geographica Socio-oeconomica, 2013, 15, 115-126. s. 124.

${ }^{44}$ Koczerga M., Motywacja przedsiębiorcza a identyfikacja okazji. Problemy Zarządzania, 2014, vol. 12, no. 3(47), 88-108. p. 90.

${ }^{45}$ Glinka B., Gudkova S., Sukces w działaniu przedsiębiorców: percepcja, wymiary, implikacje. Problemy Zarzązania, 2008, 2(20), s. 101-114
} 
The model itself (Fig. 2) implies the existence of a functional balance between two aspects in each of the four development areas: 1) balance between imagination and reason in the area of thinking; 2) balance between excitement and inhibition, and between positive and negative emotional states in the area of emotions; 3) balance between respect of others and respect of oneself in the area of relationships, and 4) balance between openness to feedback and readiness to defend one's opinions and values in the area of action.

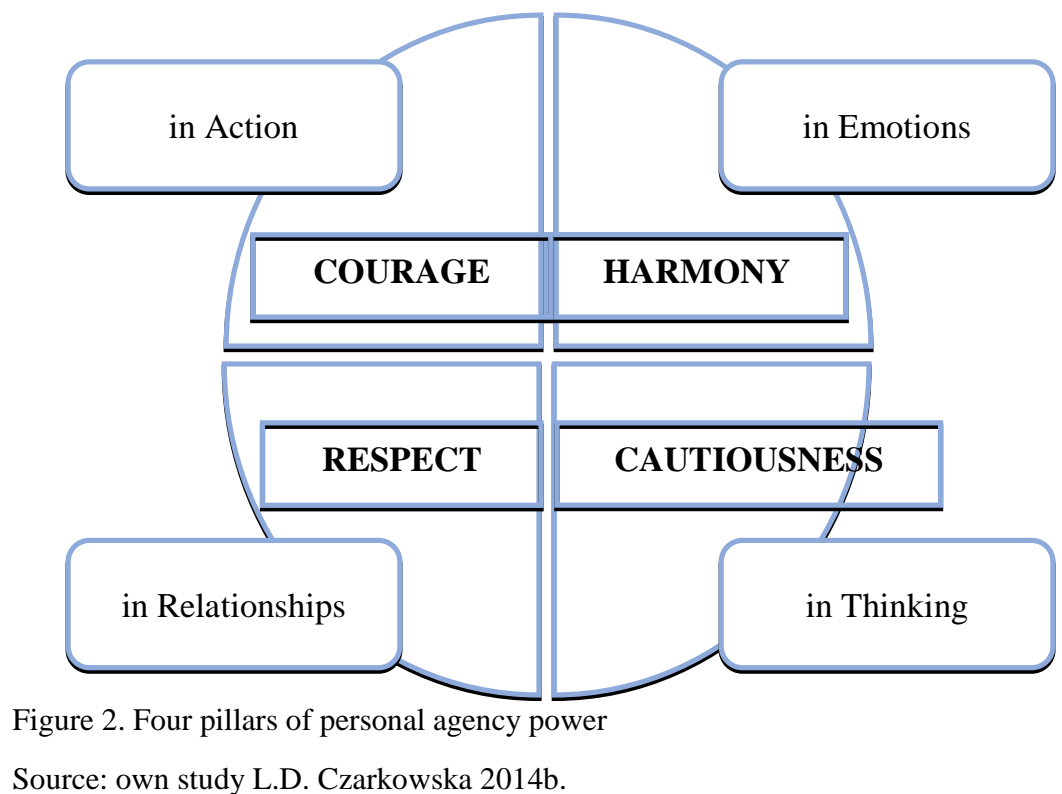

\subsection{Harmony in emotions}

In the emotional area, the symbolic denomination of the equilibrium point is HARMONY, understood as balance between excitement and inhibition processes, and as balance between the so-called positive and negative feelings. Strong emotions emerge naturally, whenever we leave our comfort zone, or when something "important" happens to us, and therefore in any situation that involves a potential threat, or touches upon values that are essential to us. Emotions bring valuable information, are a signal on what to look for and provide us with energy, and therefore motivate us to take action.

\subsection{Cautiousness in thinking}

In the area of thinking, the equilibrium point is represented by CAUTIOUSNESS, which means the perfect balance between imagination and reason. Cautiousness allows us to combine dreams with reality and ensures balance between ambitions and capabilities. This results in a combination of inspiration and logic, which allows us to come up with both new and useful ideas and solutions, and seek manners in which to achieve them.

\subsection{Respect in relationships}


In the area of relationships, the equilibrium point is RESPECT, both of others and of oneself. Mutual respect enables us to build a true partnership; openness and readiness to accept differences, both rooted in respect, bring added value. The balance between the rights we grant to ourselves and to others is called assertiveness; its opposites are submission and aggression; it allows us to build a relationship based on trust, which lowers transaction costs.

\subsection{Courage in action}

In the area of action, the equilibrium point is COURAGE, located mid-way between cowardice and bravado or buffoonery. Courage is the willingness to take responsibility for oneself and for one's decisions, to act and exceed one's limits. Courage allows us to behave in harmony with ourselves and with our values while being receptive to feedback; it lays the foundation for growth. In actions, courage helps us implement long-term strategies and short-term tactics in harmony with ourselves and with respect in relation to the views and needs of others.

In Table 3, in addition to the above values and their effects, a number of grotesque masks are listed; they represent attitudes and behaviours that we tend to adopt when we let one of the extremes prevail. The consequences of these caricatural roles are also discussed.

Table 3. Four pillars of personal agency - balance and imbalance between specific aspects

\begin{tabular}{|c|c|c|c|c|}
\hline $\begin{array}{l}\text { Value and } \\
\text { area }\end{array}$ & $\begin{array}{l}\text { Healthy } \\
\text { balance } \\
\text { between the } 1^{\text {st }} \\
\text { and the } 2^{\text {nd }} \\
\text { aspect }\end{array}$ & $\begin{array}{l}\text { Equilibrium effect } \\
\text { (“good outcomes") }\end{array}$ & $\begin{array}{c}\text { Caricature } \Rightarrow \text { possible } \\
\text { effect of the } 1^{\text {st }} \text { aspect's } \\
\text { predominance }\end{array}$ & $\begin{array}{l}\text { Caricature } \Rightarrow \text { possible } \\
\text { effect of the } 2^{\text {nd }} \\
\text { aspect's predominance }\end{array}$ \\
\hline $\begin{array}{l}\text { Harmony in } \\
\text { emotions }\end{array}$ & $\begin{array}{l}\text { 1a. Stimulation } \\
\text { and } \\
\text { 2a. Inhibition } \\
\text { 1b. Negative } \\
\text { emotions and } \\
\text { 2b. Positive } \\
\text { emotions }\end{array}$ & $\begin{array}{c}\text { Passion and } \\
\text { effectiveness } \\
\text { (commitment and } \\
\text { perseverance in } \\
\text { achieving objectives) }\end{array}$ & $\begin{array}{c}\text { Hypersensitive } \Rightarrow \\
\text { nervous breakdown; } \\
\text { or: } \\
\text { Depression } \Rightarrow \text { apathy }\end{array}$ & $\begin{array}{c}\text { Cyborg } \Rightarrow \\
\text { desensitization, lack of } \\
\text { empathy and feelings; } \\
\text { or: } \\
\text { Mania } \Rightarrow \text { chaos }\end{array}$ \\
\hline $\begin{array}{l}\text { Cautiousness } \\
\text { in thinking }\end{array}$ & $\begin{array}{l}\text { 1. Imagination } \\
\text { and } \\
\text { 2. Reason }\end{array}$ & $\begin{array}{l}\text { Inspiration and logic } \\
\text { (creating what is } \\
\text { both new and } \\
\text { valuable) }\end{array}$ & $\begin{array}{c}\text { Madman } \Rightarrow \text { insanity, } \\
\text { losing touch with } \\
\text { reality }\end{array}$ & $\begin{array}{c}\text { Labourer } \Rightarrow \text { routine, } \\
\text { stagnation }\end{array}$ \\
\hline $\begin{array}{l}\text { Respect in } \\
\text { relationships }\end{array}$ & $\begin{array}{l}\text { 1. Respect for } \\
\text { others } \\
\text { and } \\
\text { 2. Respect for } \\
\text { oneself }\end{array}$ & $\begin{array}{l}\text { Partnership and trust } \\
\text { (clarity of } \\
\text { relationships and } \\
\text { division of } \\
\text { responsibilities) }\end{array}$ & $\begin{array}{c}\text { Submission: } \\
\text { Wimp } \Rightarrow \text { submission, } \\
\text { impotence } \\
\text { or: } \\
\text { Hedger/String-puller } \\
\Rightarrow \text { losing one's face }\end{array}$ & $\begin{array}{c}\text { Aggression: } \\
\text { Despot } \Rightarrow \text { lack of real } \\
\text { authority } \\
\text { or: } \\
\text { Manipulator } \Rightarrow \\
\text { loss of credibility }\end{array}$ \\
\hline $\begin{array}{l}\text { Courage in } \\
\text { action }\end{array}$ & $\begin{array}{l}\text { 1. Openness to } \\
\text { the truth of } \\
\text { others } \\
\text { and } \\
\text { 2. Being true to } \\
\text { oneself }\end{array}$ & $\begin{array}{l}\text { Being true to oneself } \\
\text { and openness to } \\
\text { feedback } \\
\text { (overcoming of } \\
\text { internal and external } \\
\text { constraints) }\end{array}$ & $\begin{array}{c}\text { Coward } \Rightarrow \text { withdrawal, } \\
\text { escape } \\
\text { or: } \\
\text { Softie } \Rightarrow \text { surrender, } \\
\text { abandonment of } \\
\text { oneself }\end{array}$ & $\begin{array}{c}\text { Buffoon } \Rightarrow \text { bravado } \\
\text { or: } \\
\text { Battering ram } \Rightarrow \\
\text { stupidity }\end{array}$ \\
\hline
\end{tabular}

Source: own study; cf. L.D. Czarkowska (2014b).

In the project, group coaching with elements of mini-training and individual coaching sessions were employed depending on the issues discussed. The main objective of the 
process was defined as "supporting the development of self-awareness and personal agency of entrepreneurs". The project involved 41 entrepreneurs who had volunteered to participate; they were divided into five groups of up to 12 people. Each group held a series of 10 four-hour meetings dedicated to specific issues related to combining the roles of creators and entrepreneurs ${ }^{46}$. Each four-hour meeting included an introduction to the subject (a short lecture), coaching exercises in groups and individual coaching sessions. In order to provide clients with comfortable working conditions and ensure the individualization of the process, in addition to the leading coach (the author of this article), assistants coaches were present at all meetings (1-4 assistants, depending on the number of clients).

The model of four pillars of personal agency was applied in the process of coaching entrepreneurs from creative industries, with a view to assessing their current competencies and to design development activities in selected areas. Programme participants received a template form (Table 4) allowing them to analyse their own strengths and weaknesses, and to specify their desired objectives, select achievement indicators and plan all steps necessary to attain them.

On the basis of observations made during group discussions in the framework of action research and following the analysis of evidence collected during 12 in-depth interviews conducted after the completion of a six-month process of business coaching, we conclude that business coaching is an effective method that helps coachees cope with the uncertainty and volatility that are symptomatic of our times. Entrepreneurs were asked to formulate their own definition of coaching: "To me, coaching means effective action (...), awareness of my own strengths (...), the sense of agency (...), peace and strength (...), it means expanded consciousness". Specific benefits most frequently mentioned by programme participants: ${ }^{47}$

- Increased clarity in planning actions (assessing value and prioritization)

- Development of self-regulation skills (managing one's own emotional state)

- Strengthening internal motivation

- More systematic measures taken (perseverance, active attitude and consistency)

- Sense of personal agency (proactive attitude)

- Development of social skills (networking and building relationships with business partners, colleagues and clients)

Table 4. Development objectives within the model of the four pillars of agency power

\footnotetext{
${ }^{46}$ Czarkowska L.D., Model Homo Creator $i$ coaching grupowy - Jak wspierać rozwój przedsiębiorców w sektorach kreatywnych?, [in:] Oblicza kreatywności. Przedsiębiorczość $w$ sektorach kreatywnych dla początkujacych $i$ zaawansowanych, Warszawa 2014a, online publication.

47 Czarkowska L.D., The Homo Creator Model and the Development of Entrepreneurs' EQ. Group Coaching for Entrepreneurs and Action Research, [in:] Przedsiębiorczość: jednostka, organizacja, kontekst: Centrum Przedsiębiorczości i Wydawnictwo Naukowe WZ UW, Warszawa 2015b.
} 


\begin{tabular}{|c|c|c|c|c|c|c|}
\hline $\begin{array}{c}\text { Development } \\
\text { area }\end{array}$ & $\begin{array}{c}\text { Current } \\
\text { situation: } \\
\text { starting } \\
\text { point }\end{array}$ & $\begin{array}{c}\text { Desired } \\
\text { situation } \\
\text { GOAL }\end{array}$ & $\begin{array}{c}\text { Evidence: } \\
\text { indicators of } \\
\text { implementation }\end{array}$ & $\begin{array}{c}\text { Action } \\
\text { plan } \\
\text { STEPS }\end{array}$ & Resources & Time \\
\hline $\begin{array}{c}\text { Cautiousness in } \\
\text { thinking }\end{array}$ & & & & & & \\
\hline $\begin{array}{c}\text { Harmony in } \\
\text { emotions }\end{array}$ & & & & & & \\
\hline $\begin{array}{c}\text { Respect in } \\
\text { relationships }\end{array}$ & & & & & & \\
\hline $\begin{array}{c}\text { Courage in } \\
\text { action }\end{array}$ & & & & & & \\
\hline
\end{tabular}

Source: own study.

Strengths that allow entrepreneurs to effectively deal with risks and uncertainties include willingness to decide about oneself and be in control of one's life; need for achievement, greater risk tolerance, sense of personal responsibility for one's actions and internal locus of control. This package of personal predispositions typical of entrepreneurs is confirmed by the results of other studies carried out in Poland ${ }^{4849}$. At the same time, some entrepreneurs have a tendency for excessive optimism and wishful thinking, they overestimate their chances of success and fail to recognize threats, focusing selectively on success stories they have heard ${ }^{5051}$.

Business coaching allows entrepreneurs to answer a number of questions that they usually disregard, and thus may contribute to ensuring that the strategy matches the goals set and is well rooted in reality. ${ }^{52}$

\section{CONCLUSION}

${ }^{48}$ Łukaszewski W., Doliński D., Mechanizmy leżace u podstaw motywacji, [w:] Psychologia. Podręcznik akademicki, t. II, Gdańskie Wydawnictwo Psychologiczne, 2001, 441-468.

${ }^{49}$ Mazurek-Kucharska B., Psychologiczne podstawy przedsiębiorczości, 2015, http://www.google. $\mathrm{pl} / \mathrm{url}$ ? $\mathrm{s} a=t \& r c t=j \& q=\& e s r c=s \&$ source $=w e b \& c d=5 \& v e d=0 C E I Q F j A E \& u r l=h t t p \% 3 \mathrm{~A} \% 2 \mathrm{~F} \% 2$ Fwww.lbs.pl\%2Fprojekt $\% 2$ Fdobrepraktyki\%2Ffiles\%2Fartykuly\%2FBeataMK.pdf\&ei=XKWHV $Y K 7 E s X b U 4 r z g N A J \& u s g=A F Q j C N G P Q H 5 k M X d 7 A y x e H f m 1 t E B 1 X \_s e N Q \& s i g 2=c D N z I 4 H J O Z z$ $F 5 b 9 \times 2 D-c M w \& b v m=b v .96339352, d . d 24 /$ dostęp czerwiec 2016

${ }^{50}$ Łaguna M., Od czego zależy sukces $w$ prowadzeniu działalności gospodarczej? Przegląd propozycji teoretycznych, Czasopismo Psychologiczne, 2005, t. 11, nr 2, s. 142-155.

${ }^{51}$ Moczydłowska J., Pacewicz I., Przedsiębiorczość, FOSZE, Rzeszów 2007.

${ }^{52}$ Czarkowska L.D., Bussines-Coaching..., op. cit. 
Business-coaching support is particularly important in times of uncertainty, as it the development of entrepreneurship is conducive to fulfilling the following individually and socially beneficial functions: ${ }^{.3}$

- Intensive use of resources, in particular knowledge and intellectual capital;

- Speed and flexibility of response to market signals;

- Creating and testing innovation;

- Creating a protective buffer;

- Blurring boundaries between organizations and the environment.

While entrepreneurs in Poland - operating in an unpredictable and evolving political, legal and socio-economic environment, which is conditioned by multiple factors - cannot rely on any external bastion of certainty, business coaching may allow them to look inside and find a stable foothold in their own pillars of personal agency.

Coaching develops self-awareness and allows us to remain in control of our lives and to create our own reality, by taking responsibility for ourselves, for our choices and decisions. Without consciousness we are defenceless, weak and we rely heavily on circumstances. Consciousness is a fundamental resource that we should cherish: a combination of cautiousness in thinking, harmony in emotions, respect in relationships and courage in action; the four pillars of agency power of efficient entrepreneurs.

If these inner resources translate into conscious decisions and effectively implemented actions, they may allow us to achieve external success, as well as internal cohesion and a sense of fulfilment.

\section{REFERENCES}

[1] Benight Ch.C., Cieslak R., Cognitive factors and resilience: how self-efficacy contributes to coping with adversities, [in:] Resilience and mental health: Challenges across the lifespan. (eds.) S.M. Southwick, B.T. Litz, D. Charney, M.J. Friedman, Cambridge University Press 2011.

[2] Collins Ch.J., Hanges P.J., Locke E.A., The relationship of achievement motivation to entrepreneurial behavior: A metaanalysis. Human Performance, 2004, vol. 17, s. 95-117.

[3] Czarkowska L.D., Zarządzanie zintegrowane i coachingowy pierścień transformacji jako narzędzie rozwoju świadomości, [in:] Coaching jako wskaźnik zmian paradygmatu w zarzadzaniu. Poltext, Warszawa 2012.

[4] Czarkowska L.D., Model Homo Creator i coaching grupowy - Jak wspierać rozwój przedsiębiorców $w$ sektorach kreatywnych?. [in:] Oblicza kreatywności. Przedsiębiorczość w sektorach kreatywnych dla poczatkujacych i zaawansowanych, Warszawa 2014a, wydanie internetowe.

[5] Czarkowska L.D., Business-Coaching a cechy, motywy i działania przedsiębiorcze. Sztuka dokonywania wyborów i podejmowania decyzji $w$ coachingu dla przedsiębiorców, [in:] Business-Coaching jako dźwignia rozwoju przedsiębiorczości, Poltext, Warszawa 2015a, s. 35-55.

[6] Czarkowska L.D., The Homo Creator Model and the Development of Entrepreneurs' EQ. Group Coaching for Entrepreneurs and Action Research, [in:] Przedsiębior-

\footnotetext{
${ }^{53}$ Koźmiński A.K., Zarzadzanie..., op. cit. p. 165.
} 
czość: jednostka, organizacja, kontekst, Centrum Przedsiębiorczości i Wydawnictwo Naukowe WZ UW, Warszawa 2015b.

[7] Drucker P.F., Peter Drucker on the Profession of Management. Harvard Business School Publishing, Boston 1998.

[8] Drucker P.F., Innovation and Entrepreneurship, Heinemann, London 1985.

[9] Dylkiewicz R.B., Zarzadzanie przez motywacje w procesach podejmowanych decyzji gospodarczych. Przedsiębiorczość i zarządzanie, 2013, vol. XIV, no. 3, s. 87-98.

[10] Gartner W.B., Who is an entrepreneur? Is the wrong question. Entrepreneurship Theory and Practice, 1988, vol. 13, p. 47-68.

[11] Glinka B., Gudkova S., Sukces w działaniu przedsiębiorców: percepcja, wymiary, implikacje. Problemy Zarządzania, 2008, no 2(20), s. 101-114.

[12] Haber L.H., Przedsiębiorczość rynkowa parametrem produktywności człowieka w procesach pracy. Humanizacja Pracy, 1997, 4(178), s. 14-23.

[13] Kaczmarek M., Kaczmarek-Kurczak P., Przegląd metaanaliz dotyczacych zwiazku cech osobowości i przedsiębiorczości. W stronę modelu badań. Management and Business Administration. Central Europe, 2012, no. 108, pp. 49-63.

[14] Kalita B., Przedsiębiorczość jako kompetencja kluczowa w procesie uczenia się przez całe życie. Zeszyty Naukowe Politechniki Śląskiej, Seria Organizacja i Zarządzanie, 2014, z. 72, s. 51-64.

[15] Karlöf B., Business Strategy. A Guide to Concepts and Models. The Macmillan Press Ltd., London 1989.

[16] Koczerga M., Motywacja przedsiębiorcza a identyfikacja okazji. Problemy Zarządzania, 2014, vol. 12, no. 3(47), s. 88-108.

[17] Kozielecki J., O czlowieku wielowymiarowym. Eseje psychologiczne. Wydawnictwo Naukowe PWN, Warszawa 1988.

[18] Koźmiński A.K., Zarzadzanie w warunkach niepewności. Wydawnictwo Naukowe PWN, Warszawa 2004.

[19] Krajewski K., 2014, http://bizneslokalny.pl/2014/05/przedsiebiorczosc-w-polsce-wraportach-miedzynarodowych/ access: June 2016.

[20] Kraśnicka T., Koncepcja rozwoju przedsiębiorczości ekonomicznej i pozaekonomicznej. Wydawnictwo AE, Katowice 2002.

[21] Kulawiak A., Spoleczne uwarunkowania rozwoju sektora ustug $w$ matych miastach. Przyktad Uniejowa. Acta Universitatis Lodziensis, Folia Geographica Sociooeconomica, 2013, 15, s. 115-126.

[22] Łaguna M., Od czego zależy sukces w prowadzeniu działalności gospodarczej? Przeglad propozycji teoretycznych. Czasopismo Psychologiczne. 2005, t. 11, $\mathrm{nr} 2$, s. 142-155.

[23] Lukaszewski W., Doliński D., Mechanizmy leżace u podstaw motywacji, [w:] Psychologia. Podręcznik akademicki, t. II, Gdańskie Wydawnictwo Psychologiczne, 2001, s. 441-468.

[24] Maslow A.H., Towards a Psychology of Being, Princeton 1962, N.J.: D. Van Nostrand Co. 
[25] Mazurek-Kucharska B., 2015. „Psychologiczne podstawy przedsiębiorczości” http://www.google.pl/url $?$ sa $=t \& r c t=j \& q=\&$ esrc $=s \&$ source $=$ web \&cd $=5 \& v e d=0 C E I$ QFjAE\&url=http $\% 3 A \% 2 F \% 2 F w w w . l b s . p l \% 2$ Fprojekt $\% 2$ Fdobrepraktyki $\% 2$ Ffiles $\%$ 2 Fartykuly\%2FBeataMK.pdf\&ei=XKWHVYK7EsXbU4rzgNAJ\&usg =AFQjCNGPQ H5kMXd7AyxeHfm1tEB1X_seNQ\&sig2=cDNzI4HJOZzF5b9x2D$c M w \& b v m=b v .96339352, d . d 24 /$ dostęp czerwiec 2016

[26] McClelland D.C., Need achievement and entrepreneurship: A longitudinal study. Journal of Personality and Social Psychology, 1965, vol. 1, s. 389-392.

[27] Moczydłowska J., Pacewicz I., Przedsiębiorczość. FOSZE, Rzeszów 2007.

[28] Obłój K., Strategia organizacji. W poszukiwaniu trwałej przewagi konkurencyjnej. Polskie Wydawnictwo Ekonomiczne, Warszawa 2007.

[29] Praszkier R., Zwykli ludzie czy herosi? Motywacje przedsiębiorców społecznych. Trzeci Sektor, 2006, nr 4, s. 35-42.

[30] Piasecki B. (red.), Ekonomika i zarzadzanie mała firma. Wydawnictwo Naukowe PWN, Warszawa-Lódź 2001.

[31] Piecuch T., Cechy przedsiębiorcy. Ekonomika i Organizacja Przedsiębiorstwa, 2009, vol. 2, no. 708, s. 17-26.

[32] Piecuch T., Przedsiębiorczość. Podstawy teoretyczne. Wydawnictwo C.H. Beck, Warszawa 2010.

[33] Rauch A., Frese M., Let's put the person back into entrepreneurship research: A meta-analysis on the relationship between business owners' personality traits, business creation, and success. European Journal of Work and Organizational Psychology, 2007, vol. 16, s. 353-385.

[34] Strojny J., Ksztaltowanie postawy przedsiębiorczej - procesy socjalizacji i autokreacji, [w:] Ksztaltowanie postaw przedsiębiorczych a edukacja ekonomiczna, Fundacja Promocji i Akredytacji Kierunków Ekonomicznych, Warszawa 2007.

[35] Strzałecki A., Czołak D., Osobowościowe i temperamentalne czynniki warunkujace osiaganie sukcesu w przedsiębiorczości. Przegląd Psychologiczny, 2005, vol. 48, no. 2, s. 133-151.

[36] Sudoł S., Przedsiębiorczość - jej pojmowanie, typy i czynniki ja kształtujące. Problemy Zarządzania, 2008, 2/2008(20).

[37] Szewczuk W. (ed.), Encyklopedia psychologii. Fundacja Innowacja, Warszawa 1998.

[38] Wiatrak A.P., 2003. Pojęcie przedsiębiorczości, jej cele i rodzaje, [w:] K. Jaremczuk (red.) Uwarunkowania rozwoju przedsiębiorczości - szanse i zagrożenia. Wydawnictwo Państwowej Wyższej Szkoły Zawodowej, Tarnobrzeg 2003.

[39] Zhao H., Seibert S.E., The Big Five personality dimensions and entrepreneurial status: A meta-analytic review. Journal of Applied Psychology. 2006, vol. 91, s. $259-271$.

[40] Zhao H., Seibert S.E., Lumpkin G.Th., The relationship of personality to entrepreneurial intentions and performance: A metaanalytic review. Journal of Management. 2010, vol. 36, s. 381-404.

[41] http://www.weforum.org/.

[42] http://www.heritage.org/index/ranking. 


\section{CZTERY FILARY MOCY SPRAWCZEJ PRZEDSIEBIORCY. HARMONIA W EMOCJACH, ROZWAGA W MYŚLENIU, SZACUNEK W RELACJACH I ODWAGA W DZIALANIU}

Artykuł przedstawia kontekstowe i osobiste uwarunkowania sukcesu przedsiębiorców, z uwzględnieniem zarówno czynników strukturalnych: polityczno-społecznych, ekonomicznych, technologicznych czy prawnych jak też indywidualnych, jednostkowych. Autorka prezentuje przegląd obecnych w literaturze modeli definiujących przedsiębiorczość w kategoriach: zestawów cech osobowościowych, opisu postaw, określonego rodzaju kompetencji, podejmowanych działań, czy procesu; ukazuje też wyniki badań nad przedsiębiorczymi cechami, postawami, motywacjami i działaniami. Przy koncepcjach osobowościowych opisany został Homo Hubris - model idealnego przedsiębiorcy, zdolnego do zachowań transgresyjnych. Artykuł zawiera także zestawienie cech utrudniających i cech ułatwiających podejmowanie działań przedsiębiorczych ze szczególnym uwzględnieniem roli uogólnionego poczucia własnej skuteczności (ang. Self-Efficacy). Ponadto w artykule zaprezentowany został zakres zastosowań business-coachingu, a także cele i korzyści płynące z tego rodzaju specjalistycznej usługi adresowanej do właścicieli przedsiębiorstw. Część aplikacyjna artykułu zawiera opis autorskiego modelu „Czterech filarów osobistej mocy sprawczej przedsiębiorcy: Harmonii w emocjach, rozwagi w myśleniu, szacunku w relacjach i odwagi w działaniu". Autorka przedstawiła także przykład użycia tego modelu podczas coachingu grupowego, z którego skorzystało 41 przedsiębiorców biorących udział w projekcie „Przedsiębiorczość w sektorach kreatywnych”. Do głównych korzyści uzyskanych dzięki uczestnictwie $\mathrm{w}$ business-coachingowym procesie przedsiębiorcy zaliczyli: rozpoznanie posiadanych zasobów osobistych, własnych mocnych stron i talentów oraz zidentyfikowanie obszarów do dalszego rozwoju; wzrost klarowności w planowaniu działań i ustaleniu priorytetów; rozwój umiejętności zarządzania własnym stanem emocjonalnym; wzmocnienie wewnętrznej motywacji, zaangażowania i konsekwencji; wzmocnienie poczucia sprawstwa i proaktywnej postawy oraz rozwój kompetencji społecznych przydatnych do nawiązywania i pogłębiania relacji z kontrahentami, współpracownikami i klientami.

Słowa kluczowe: coaching, przedsiębiorczość, inteligencja emocjonalna, motywacja wewnętrzna, sektor kreatywny.

DOI:10.7862/rz.2016.hss.61

Przestano do redakcji: wrzesień $2016 r$.

Przyjęto do druku: grudzień $2016 r$. 